\title{
Przemoc, peryferie i dzikość natury Obraz wsi w Malowanym ptaku Jerzego Kosińskiego
}

\section{The violence, outskirts and wildness of the nature Image of the village in The Painted Bird by Jerzy Kosiński}

Można powiedzieć, że motyw wsi oraz idące z nim w parze zainteresowanie losem jej mieszkańców towarzyszą polskiej literaturze od dawien dawna, a właściwie od samych jej początków. Można by nawet zaryzykować twierdzenie, że w niektórych epokach literackich, jak choćby Młoda Polska, wieś i lud stały się wręcz obsesyjnie poruszanym tematem tak w prozie, jak i poezji. $Z$ reguły, poeci i pisarze opisywali piękno polskiej wsi, pracowite życie jej mieszkańców, tworzyli obrazy mniej lub bardziej bliskie prawdzie czy fikcji literackiej. Różne epoki literackie ukazywały różnorakie obrazy wsi, skupiając się na sielankowości arkadyjskiego życia albo przeciwnie - na wielości krzywd doznawanych przez chłopów nieuznawanych za prawowitych obywateli państwa polskiego czy w ogóle za ludzi. Na szczególną uwagę dzięki opozycji wobec nostalgicznego, sielankowego obrazu wsi, budowanego w literaturze polskiej od Mikołaja Reja, poprzez Jana Kochanowskiego, aż do Adama Mickiewicza, zasługują epoki Oświecenia oraz Pozytywizmu'. Charakteryzowały się one bardziej realnym, naturalistycznym spojrzeniem na problematykę wiejską, poruszając temat niesprawiedliwości społecznej, nędzy, zabobonów i niezawinionych cierpień ludu wiejskiego spowodowanych przez wyższe warstwy społeczeństwa. Już nie idylla wiejskiego, prostego życia, a konflikt między dworem a wsią stał się

1 Z całego, niezmiernie obszernego obszaru literatury polskiej tych okresów literackich, z panteonu jej twórców szczególnie zainteresowanych tematyką polskiej wsi można wymienić: Ignacego Krasickiego, Stanisława Staszica, Bolesława Prusa, Elizę Orzeszkową, Marię Konopnicką. 
przewodnim motywem wielu utworów literackich. Jak sądzę, najważniejszą i najpoważniejszą próbą zmierzenia się z problematyką wiejską w literaturze polskiej czasów współczesnych pozostają Chtopi Władysława Reymonta.

Ta wielowarstwowa w swych znaczeniach i wielowątkowa epopeja urasta do rangi mitu polskiej wsi oraz kreuje mit bohatera zbiorowego, jakim w powieści polskiego noblisty stają się właśnie chłopi, warstwa społeczna, w której autor widzi najbardziej wartościową, najszlachetniejszą, a jednocześnie najbardziej niedocenianą część narodu. Trudno się dziwić W. Reymontowi, synowi wiejskiego organisty, że to polską wieś uczynił miejscem akcji swej najważniejszej powieści. Podobnie jak w przypadku innych artefaktów kultury wysokiej ze sfery sztuki i wyobraźni poetyckiej, tekst literacki powstaje, przynajmniej pośrednio, pod znaczącym wpływem kontekstów danej kultury i stosunków społecznych, w ramach których funkcjonuje jego autor. Badanie ram kulturowych twórczości literackiej zajmuje antropologów oraz teoretyków literatury, głoszących (zresztą ze wszech miar słuszny) pogląd o kulturowych źródłach wyobraźni literackiej twórców tekstów poddawanych analizom ${ }^{2}$.

Wiele postaci z historii polskiej wsi trafiło na karty literatury i zostało włączonych w zbiór mitologii tożsamości zbiorowej oraz pamięci społecznej. Nie zawsze były jednoznacznie pozytywne jak Bartosz Głowacki. Dla niektórych autorów Jakub Szela stał się wręcz archetypicznym fantazmatem $^{3}$ buntu przeciwko uciskowi opresyjnego, niesprawiedliwego systemu społecznego Polski szlacheckiej, a dla innych krwawym upiorem i synonimem zdrajcy ${ }^{4}$.

W „nurcie wiejskim” literatury współczesnej możemy odnaleźć dwojaki obraz polskiej wsi: sielankowej, harmonijnej krainy zamieszkanej przez prostych, ale szczęśliwych autochtonów oraz miejsce bezwzględnej walki o przetrwanie, obszar dzikości nieskrępowanej kulturowymi normami, ze względu na bliskość natury miejsce wywołujące u ludzi „zwierzęce” instynkty. I taka jest właśnie powieść Jerzego Kosińskiego Malowany ptak. W odróżnieniu od powieści Wiesława Myśliwskiego czy dobrze znanych

2 Zob.: J. Culler, Teoria literatury, przel. M. Bassaj, Warszawa 1998; Kulturowa teoria literatury. Gtówne pojęcia i problemy, red. M. Markowski, R. Nycz, Kraków 2010; Antropologia literatury. Interpretacje i studia, red. E. Feliksiak, Kraków 20I4; M.P. Markowski, Antropologia i literatura, „Teksty Drugie” 2007, nr 6.

3 Fantazmat rozumiem za Marią Janion jako rodzaj kulturowego wyobrażenia, funkcjonującego w wyobraźni społecznej, pamięci oraz dyskursie kultury wysokiej. Zob. tejże: Kobiety i duch inności, Warszawa 2006, s. 6.

4 Dużą część swojej pracy poświęcił temu tematowi Franciszek Ziejka. Zob.: tegoż: Ztota legenda chtopów polskich, Warszawa 1984, s. 78-82, 151-198, 233-264. 
z refleksji etnologów książkom Edwarda Redlińskiego ${ }^{5}$ zawiera obraz polskiej wsi z najczarniejszego snu, koszmaru rodem z piekielnych kręgów przemocy, spotęgowanej przez wojnę.

Wieś z Malowanego ptaka znajduje się w obszarze dalekich peryferii kultury i cywilizacji, w ostępach dzikich lasów, bagien i rzecznych rozlewisk, wobec której Taplary E. Redlińskiego zdają się stanowić ostoję spokoju, normatywnego i moralnego porządku, technologicznego postępu.

\section{Jerzy Kosiński - dziecko Holocaustu i jego demony Najważniejsza powieść: autobiografia czy autofikcja?}

Zanim zajmę się literackim obrazem polskiej wsi stworzonym przez J. Kosińskiego, warto jemu samemu oraz jego przeżyciom z dzieciństwa poświęcić nieco miejsca. To one bowiem stały się kanwą najważniejszej powieści tego pisarza, która jako jedyna przetrwała próbę czasu i znajduje się w amerykańskim kanonie obowiązkowych lektur dotyczących Zagłady. J. Kosiński wśród nowojorskiego środowiska literackiego przedstawiał się jako „dziecko Holocaustu", twierdząc, że opisane w Malowanym ptaku przeżycia są prawdziwe, a sama powieść oparta jest na faktach. Stało się to później przyczyną wielu nieporozumień i kłopotów pisarza, zarówno wśród amerykańskich dziennikarzy i twórców, jak też działaczy polonijnych. Po wielokroć oskarżano go o plagiat, kłamstwo, szkalowanie Polski czy nawet korzystanie z usług ghostwritera. J. Kosiński miał bowiem kłopoty z pisaniem w języku angielskim i musiał korzystać, przynajmniej na początku pobytu w Stanach Zjednoczonych, z usług thumaczy.

Korzystam tu z wydania książki w przekładzie Tomasza Mirkowicza, z roku 1995, do której J. Kosiński, funkcjonując jedyny raz jako narrator wszechwiedzący, dołączył krótką przedmowę umiejscawiającą akcję $M a-$ lowanego ptaka w bliżej nieokreślonym miejscu Europy Wschodniej, nie wskazując wyraźnie na Polskę. O najsłynniejszej książce J. Kosińskiego recenzenci pisali jako o arcydziele literatury, wstrząsającej relacji z Holocaustu, ale najczęściej używanym epitetem była: „kontrowersyjna”. I rzeczywiście, powieść pełna jest scen przemocy, seksu, opisów brutalnych ludzkich zachowań, dzikości natury i bliskich jej porządkowi mieszkańców wsi. W tym miejscu należy jednak dokonać pewnego istotnego zastrzeżenia,

5 Zwłaszcza Konopielka E. Redlińskiego bywała obiektem błyskotliwych analiz takich antropologów kultury, jak Ludwik Stomma (tegoż, Antropologia kultury wsi polskiej XIX wieku, Warszawa 1986) czy Michał Rydlewski (tegoż, "Spór o kosę” $w$ Konopielce Edwarda Redlińskiego a zmienne treści percepcyjne schematów pojęciowych, „Etnografia Polska" 2017, t. LXI, z. I-2). 
koniecznego dla dalszych analiz tekstu książki. Nie należy łączyć, a tym bardziej całkowicie utożsamiać narratora Malowanego ptaka i jego przeżyć z postacią i biografią samego J. Kosińskiego. Antropolog kultury czy literaturoznawca nie powinien poszukiwać mistyfikacji, podążać tropem Joanny Siedleckiej i jej Czarnego ptasiora dekonstruującego wojenny życiorys pisarza usankcjonowany przez niego samego jako prawdziwy bądź prawdzie bliski ${ }^{6}$.

Powieść nie jest bowiem autobiografią, a badacz tekstów kultury, w tym tekstów literackich, powinien mieć świadomość niebezpieczeństw, jakie niesie ze sobą dosłowne traktowanie literackich źródeł pamięci autobiograficznej i bezrefleksyjnego, całkowitego utożsamiania autora z narratorem. Tym bardziej, jeśli przedstawiane przeżycia bohatera tekstu literackiego są związane $\mathrm{z}$ traumą i bazują na jej pamiętaniu' ${ }^{7}$ a narracyjne kontinuum jest tylko imitacją kontinuum pamięci. Widać to wyraźnie na przykładzie książki Güntera Grassa Przy obieraniu cebuli, a zwłaszcza jej fragmentów opisujących służbę bohatera (nie do końca utożsamianego z autorem) w Waffen ss „Frundsberg”.

Autobiografia jest próbą czerpania z zasobów pamięci i wyobraźni, a pamięć nie jest bezstronna, służąc kreacji „Ja” spójnego z autodefinicjami jej autora i działaniem mitotwórczego filtru epistemy9. Pamięć i wyobraźnia współgrają ze sobą przy tworzeniu narracji literackiej. Tym bardziej w przypadku autorów o wielkiej skłonności do mitotwórstwa (jak J. Kosiński) bazujących na własnych przeżyciach oraz biografii, czerpiących przy tym z zasobów pamięci kulturowej i społecznej. Jak sądzę, porównanie obu książek i odczytanie narracji G. Grassa oraz J. Kosińskiego może sprawiać pewien kłopot. Malowany ptak jest bowiem relacją ofiary i świadka Zagłady, podczas gdy Przy obieraniu cebuli stanowi próbę zmierzenia się autora z problemem winy i odpowiedzialności sprawcy za udział w wojnie po stronie hitlerowskich Niemiec.

6 Szczegółowym tropem wojennej wędrówki J. Kosińskiego podążyli J. Siedlecka i James Park Sloan, jego biografowie. Poszukiwali faktów, prawdy, wydarzeń i realnych postaci, które stały się kanwą dla opisywanych w Malowanym ptaku strasznych przeżyć Chłopca. Nie wydaje się to najwłaściwszą drogą dla literaturoznawców i antropologów kultury, prowadzącą do odczytania znaczeń i symboliki obecnych w tej powieści, a przynajmniej nie powinno być najważniejsze. Zob.: J. Siedlecka, Czarny ptasior, Warszawa 2011.

7 Szczegółowo pisałem na ten temat w książce: Pomiędzy pamięcią autobiograficzna a zbiorowa. Polska ludowa i stan wojenny w narracjach tódzkich nauczycieli, Łódź 2016, s. 86-92, 143-149.

8 Zob.: G. Grass, Przy obieraniu cebuli, przel. S. Bałut, Gdańsk 2007, s. 7, 35.

9 M.Zaleski, Formy pamięci, Gdańsk 2004, s. 62; B. Skarga, Tożsamoś́́ Ja ipamięć, „Znak” 1995, nr 5, s. 18. 
Narracyjną formą, obecną w Malowanym ptaku, jest opowieść o stracie charakterystyczna dla pisarstwa autobiograficznego i w tej formie literackiej najwyraźniej wyrażana, widoczna w przywoływanej wcześniej książce G. Grassa ${ }^{10}$. Jest ona także literackim przykładem próby przepracowania w pamięci doświadczonej traumy oraz trajektorii wojennych losów wspólnoty.

Pamięć autobiograficzna zawierająca zapis przeżytej traumy jest fragmentaryczna i niepełna. Problem odtwarzania sytuacji traumatycznej komplikuje dodatkowo proces tłumienia blokujący dostęp do wspomnień"

Wspominanie traumy, a więc także pisanie o niej, jest szczególnie trudnym procesem. Wiemy, że trauma:

pojawia się w następstwie wydarzenia odznaczającego się szczególną intensywnością. Doświadczający podmiot staje się niezdolny do jej przyswojenia i adekwatnej reakcji na nią. Oznacza ona wstrząs i jego patogenne skutki dla psychiki jednostki. Traumę charakteryzuje nadmierna liczba niemożliwych do opanowania bodźców: nie sposób ich psychicznie opanować ani włączyć w porządek reprezentacji i rozumienia. Jest to przeżycie, które w krótkim czasie silnie pobudza psychikę. Nie można się go pozbyć ani przyswoić za pomocą dostępnych środków i procedur. To gwałtowne i szokowe rozbicie jedności, wyrwa, pęknięcie ${ }^{12}$.

Traumy mogą dotyczyć całych zbiorowości, naznaczać swym piętnem pokolenia wojny, Holocaustu, czystek etnicznych i ludobójstwa. Kiedy dotykają dużej grupy, a nawet całych narodów, doświadczają ich jednostki będące częścią tejże wspólnoty.

Jeszcze jedna właściwość pamięci w sytuacji doświadczenia traumy powoduje, że jest ona szczególnie podatna na zniekształcenia i obciążona akomodacją treści pamięci społecznej oraz kulturowej. Przebywający na emigracji w Stanach Zjednoczonych Bruno Bettelheim opisał swe doświadczenia obozowe z Buchenwaldu i Dachau. Nie przyszło mu to łatwo, mimo że jako psycholog zajmował się zaburzeniami w funkcjonowaniu osobowości. Obserwowanie samego siebie, współwięźniów i esesmanów było tym trudniejsze, że wszystkie zachowania i wydarzenia musiał zapamiętać. B. Bettelheim

10 Zob.: M. Okupnik, Fenomen pamięci. O trudnościach badań narracji autobiograficznych o stracie, „Acta Universitatis Lodzensis. Folia Sociologica” 20I2, nr 4I, s. IOI-I2I.

11 T. Maruszewski, Pamięć autobiograficzna, Gdańsk 2005, s.31.

12 K. Bojarska, Trauma, [w:] Modimemorandi. Leksykon kultury pamięci, red. M. Saryusz-Wolska, R. Traba, Warszawa 20I4, s. 501 . 
„zauważył jednak, że było to niezwykle utrudnione wskutek niedożywienia oraz innych czynników, które osłabiają funkcjonowanie pamięci [...]. Warunki obozowe wywarły na jego pamięć szkodliwy wpływ: to, co przedtem działało w sposób automatyczny i naturalny, wymagało teraz świadomego wysiłku" ${ }^{13}$. Dodatkowym czynnikiem osłabiającym działanie pamięci w sytuacji traumy była upośledzona przez ciągły stres zdolność percepcji. Młody J. Kosiński, mimo przebywania w stosunkowo bezpiecznym otoczeniu polskiej wsi, ciągły stres odczuwał przez całą okupację hitlerowską. Jego rodzinie oraz ukrywającym ich polskim wieśniakom groziła okrutna śmierć z rąk niemieckiego okupanta. Ucieczka z Łodzi, podróż do Sandomierza, potem na wieś do Dąbrowy Rzeczyckiej, porzucenie dotychczasowej tożsamości, języka, imienia i nazwiska musiały być dla sześcioletniego chłopca zupełnie niezrozumiałe i budzące lęk.

Trauma, jakiej doświadczył w dzieciństwie J. Kosiński, choć w jego przypadku nie tak okrutna i tożsamościowo dezintegrująca jak ta będąca udziałem reszty pokolenia Zagłady, również mogła (i zapewne musiała) spowodować pewne zniekształcenia pamięci. Wiemy także, że:

pamięć jakiegokolwiek zdarzenia i faktu jest amalgamatem informacji pochodzących nie tylko z pamięci, lecz także z przekonań i przypuszczeń jednostki oraz jej otoczenia. Silny wpływ na to, jakie informacje odtwarza dana osoba, wywiera jej otoczenie społeczne. Może ono zniekształcać pamięć jakiegoś zdarzenia lub doprowadzać do odtwarzania informacji, z którymi jednostka nigdy się nie zetknęła. Syndrom pamięci fałszywej unaocznił, że zmiany zawartości pamięci mogą przebiegać w sposób niekontrolowany przez jednostkę i może ona nie zdawać sobie sprawy z tego, że przywołuje informacje, z którymi nigdy się nie zetknęła ${ }^{14}$.

Pamięć traumy jest szczególnie obciążona negatywnymi wspomnieniami silnie oddziałującymi na jednostkę. Aby poddać ją przepracowaniu, może ona doświadczać przymusu opowiadania o niej, ujmowania swoich doznań w formę literacką o charakterze autobiograficznym bądź zawierającą elementy autobiografizmu. Taka jest twórczość pokolenia Holocaustu opisująca krańcowe doświadczenia z niemieckim totalitaryzmem. Sądzę, że podobny przymus opowiadania o wcześniej głęboko skrywanej traumie odczuwał J. Kosiński, tworząc autofikcję w Malowanym ptaku. Jego

13 D. Draaisma, Dlaczego życie ptynie szybciej, gdy się starzejemy, przel. Ewa Jusewicz-Kalter, Warszawa 2006, s. 149 .

14 T. Maruszewski, Pamięć indywidualna, [w:] Modi memorandi..., dz. cyt., s.331. 
najsłynniejsza powieść „jawi się jako literacki przekaz wiedzy o jednostkowym doświadczaniu czasów, przeżywanych przez całe pokolenie [...]. Strukturą swą, ta najbardziej w Polsce kontrowersyjna książka Jerzego Kosińskiego, upodabnia się do mechanizmu pamięci, gdzie mieszają się rzeczywistość i fantazja" "15. J. Kosiński pisał powieści zawierające swego rodzaju klucz ${ }^{16}$ :

postać narratora lub głównego bohatera nieodmiennie sugerowała bliskie pokrewieństwo z autorem. Kosiński zwykł określać własną twórczość jako „autofikcję”, chętnie podtrzymując tezę o podobieństwie swojej biografii do losów literackich protagonistów. Historia Chłopca z Malowanego ptaka, który utracił na pewien czas mowę w wyniku cierpień i tortur, jakie przeszedł w czasie wojny, uchodziła ogólnie za jego własną ${ }^{17}$.

Przyczynił się do tego sam autor, sugerując obecny w powieści autobiografizm recenzującemu ją Eliemu Weiselowi:

początkowo reakcja [...] była chłodna. Kosiński znał jednak trochę Weisela i udało mu się napomknąć, że powieść zasadniczo jest autobiografią. Wzmianka, że Malowany ptak jest kroniką autentycznego ludzkiego cierpienia, była kluczem, którego Weisel potrzebował i [...] recenzja zatytułowana Ofiara wszystkich usankcjonowała książkę jako autentyczne świadectwo holocaustu ${ }^{18}$.

W opiniach amerykańskich krytyków pojawiały się słowa: relacja, wyznanie, testament, dokument i świadectwo, wzmacniając błędne przekonanie o dokumentalnej wręcz faktografii powieści J. Kosińskiego. Pisarz po jakimś czasie, a zwłaszcza po wydaniu Malowanego ptaka w Polsce, próbował skierować czytelników i krytykę literacką w stronę autofikcji, nie zaś autobiografii, ale gra $\mathrm{z}$ własną biografią i historią Holocaustu okazały się co najmniej niefortunne dla odbioru powieści przez krajowego czytelnika. Jednak to nie J. Kosiński wymyślił autofikcję jako rodzaj literatury i metodę pisarstwa wykorzystującego zmityzowaną autobiografię i pamięć:

15 A.U. Przychodzka, Zatracona tożsamość Jerzego Kosińskiego. Doświadczanie Holocaustu, Łódź 2006, s. 79-80.

16 Nie są to jednak typowe „powieści z kluczem”, czyli utwory literackie przedstawiające prawdziwe postaci i wydarzenia pod zmyślonymi lub zmienionymi imionami i nazwami. Zob.: Stownik rodzajów i gatunków literackich, red. G. Gazda, Warszawa 2012.

17 H. Dasko, Odlot malowanego ptaka, Warszawa 2009, s. IIO-III.

18 J.P. Sloan, Jerzy Kosiński. Biografia, przeł. E. Kulik-Bielińska, Warszawa 1997, s. 204. 
francuski powieściopisarz i literaturoznawca Serge Doubrovsky definiował ją jako fikcję faktów. W Ameryce uprawiali ją Joseph Heller i Philip Roth. W Polsce, w pokoleniu Kosińskiego i nieco młodszym, autofikcja to jedna z najpopularniejszych metod literackich. Uprawiali ją Marek Hłasko, Marek Nowakowski, Andrzej Brycht, Edward Redliński i Andrzej Zuławski. Stworzyli obszerny i ważny kanon utworów opartych bezpośrednio na biografiach ich autorów ${ }^{19}$.

Każde zapamiętane doświadczenie jest w pewnym sensie po trosze fikcją. Oczywiście, na powieść J. Kosińskiego należy patrzeć jako na bliską sferze mitu, mitologii, poruszającą uniwersalne problemy odnoszące się do ogólnoludzkiej kondycji, zawierającą elementy i konteksty bliskie każdemu antropologowi kultury. Myślę tu, na przykład, o opozycjach i kategoriach: natura - kultura, swój - obcy, orbis interior - orbis exterior, centrum - peryferie, wędrówka, ale też o symbolach i archetypach związanych z figurami dziecka, kobiety, zła, dobra, skazy/zmazy, winy i ofiary. W końcu, jak mawiał Mircea Eliade ${ }^{20}$, literatura jest córką mitologii, a jako taka, wymyka się dwuwartościowej logice: prawda - fałsz.

\section{Wojenna wędrówka i dziecko w obcym świecie dzikiej natury Wieś jako peryferie pełne przemocy}

Jesienią 1939 roku, w pierwszych tygodniach drugiej wojny światowej, rodzice sześcioletniego chłopca z dużego wschodnioeuropejskiego miasta wysłali go do odległej wioski, aby tam - podobnie jak tysiące innych dzieci - znalazł bezpieczne schronienie. Pewien człowiek, który udawał się na wschód, zgodził się, za sowitym wynagrodzeniem, umieścić dziecko u chłopskiej rodziny. [...] Wsie, w których przyszło mu spędzić następne cztery lata, różniły się pod względem etnicznym od jego miejsca urodzenia. Tubylcza ludność, odizolowana od świata, pozbawiona dopływu świeżej krwi, miała jasną cerę, jasne włosy i niebieskie lub szare oczy. Chłopiec był ciemnowłosy, czarnooki i śniady. Posługiwał się językiem warstwy wykształconej, prawie niezrozumiałym dla wieśniaków ze wschodu. Uważano go za przybłędę, Cygana lub Żyda, a udzielanie schronienia Cyganom i Żydom, zamykanym w gettach i obozach zagłady, narażało jednostki i społeczności na najsroższe kary ze strony Niemców ${ }^{21}$.

19 H. Dasko, dz. cyt., s. I81-I82.

20 M.Eliade, Próba labiryntu. Rozmowy z Claude-Henri Rocquetem, przeł. K. Środa, Warszawa 1992; tegoż, Aspekty mitu, przeł. P. Mrówczyński, Warszawa 1998.

21 J. Kosiński, Malowany ptak, przeł. T. Mirkowicz, Warszawa 1995, s.9-10. 
Właściwie ten cytat wystarczy, by zrozumieć sytuację bohatera - bezimiennego Chłopca. Warunki wojny, zagrożenia i spowodowanej nimi wędrówki, a właściwie ucieczki, sytuują go w zaświatowym obszarze obcości, zarówno jako osobę wędrowca, jak i odmieńca - obcego. Już na pierwszy rzut oka jest inny, a to wrażenie oprócz wyglądu pogłębiają: niezrozumiała mowa, nieznajomość obyczaju, wierzeń i warunków bytowania wiejskiej społeczności, jak też umiejętności koniecznych dla przeżycia w czasie wędrówki. Tego wszystkiego Chłopiec będzie musiał się nauczyć. Jego wędrówka jest okupiona cierpieniem, mniejszym lub większym, tak psychicznym, jak i fizycznym. Ciągłe tortury, jakim jest poddawany, i okropności, jakich doświadcza, sprawiają, że jego droga ucieczki jest wędrówką przez piekło. W drodze zapomina, po co i gdzie wędruje, skupiając się na przetrwaniu kolejnych dni. Jest też bacznym obserwatorem, ucząc się wszystkiego, co może pomóc mu przeżyć. Blakną wspomnienia o domu, czystych, eleganckich ubraniach, zamożnych rodzicach i pięknych, kosztownych zabawkach. Kolejny fragment wstępu jest krótkim opisem wsi, jakie widzimy w powieści. Zawiera wszystko, co autor później wykorzysta w obrazie infernalnego obszaru wędrówki po wiejskich okolicach:

Wioski w tej okolicy były zapomniane przez wieki. Niedostępne, położone daleko od ośrodków miejskich, znajdowały się w jednym z najbardziej zacofanych obszarów Europy Wschodniej. Nie istniały tam szkoły i szpitale, nie znano elektryczności, a mosty i brukowane drogi stanowiły rzadkość. Mieszkańcy niewielkich osad żyli tak samo, jak ich przodkowie. Wioski toczyły waśnie o dostęp do rzek, lasów i jezior. Jedynym prawem było prastare prawo silnych i bogatych do narzucania swojej woli słabym i ubogim. Ludność, podzieloną na katolicką i prawosławną, łączyła tylko zabobonność oraz niezliczone choroby, nękające zarówno wieśniaków, jak i zwierzęta. Tutejsi chłopi byli ciemni i okrutni, choć nie z własnej winy. Ziemia była marna, klimat surowy. Rzeki, z których ryby wybrano niemal doszczętnie, często wylewały na pastwiska i pola, przemieniając je w bagna. Znaczną powierzchnię zajmowały rozległe moczary i trzęsawiska, a gęste lasy od niepamiętnych czasów zapewniały schronienie bandom buntowników i przestępców. Niemiecka okupacja tylko pogłębiła nędzę i zacofanie regionu ${ }^{22}$.

W tym krótkim fragmencie każdy etnolog odnajdzie znajome elementy opisu przedwojennych warunków życia w dzikich, odległych terenach eksplorowanych przez odważnych badaczy. Socjolog zobaczy zaś przedstawienie

22 Tamże, s. ıo-II. 
tradycyjnej, sztywnej struktury społecznej dawnej wsi, zasad rządzących kontaktem z innymi społecznościami oraz powody takiego, a nie innego funkcjonowania instytucji społecznych. Wydaje się, że opisy terenów z wędrówki Chłopca, położonych w jednym z najbardziej zacofanych rejonów Europy Wschodniej, stworzone przez J. Kosińskiego, prowadzą nas w okolice Polesia, doskonale znanego etnografom, uznawanego za najbardziej zacofany i dziki obszar przedwojennej Polski. Wrażenie pogłębiają fragmenty powieści szczegółowo ukazujące obyczaje ludu wiejskiego, sposoby leczenia chorób czy praktykowania magii. Dodatkowo ważne postaci, jak ptasznik Lech i znachorka Olga, zdają się pochodzić wprost z kart etnograficznych opracowań. Nieco światła na tereny, na których dzieje się akcja Malowanego ptaka, rzuca fragment biografii J. Kosińskiego autorstwa Jamesa Sloana dotyczący redakcji tłumaczenia tekstu:

Stopniowo opadły pozory i choć nigdy nie zostało to wprost powiedziane, stało się jasne, że autorem rękopisu jest Kosiński.

- Czy ty...? - zaczynał pytanie Skinner.

- Chłopiec, Chłopiec - poprawiał go Kosiński.

- Czy Chłopiec...? - zmieniał pytanie Skinner.

- Nie pamiętam - odpowiadał Kosiński.

Chłopiec, tłumaczył później Kosiński, był jego fikcyjnym „ja”.Z opisu terenu Skinner wywnioskował, że akcja książki rozgrywa się na bagnach Prypeci, Kosiński nie określił jednak tego jasno ${ }^{23}$.

Wschodnia Europa, pogranicze Białorusi, Ukrainy, Polski, Prypeć i Soża, Dniepr, Niemen i Bug, Dregowicze i Poleszucy, Polesie. Etnografowi łatwiej zaryzykować rozpoznanie miejsc realnie istniejących i opisanych w literaturze przedmiotu, na podstawie których J. Kosiński stworzył obraz wsi i jej mieszkańców w Malowanym ptaku.

Malownicze opisy Polesia możemy odnaleźć w literaturze podróżniczej Antoniego Ferdynanda Ossendowskiego ${ }^{24}$, wspomnieniowej - Ksawerego Pruszyńskiego $^{25}$ i etnograficznej - Kazimierza Moszyńskiego ${ }^{26}$. Nie wiemy,

23 J.P. Sloan, dz. cyt., s. 188.

24 A.F. Ossendowski, Polesie, Poznań 2010.

25 K. Pruszyński, Podróź po Polsce, Warszawa 2000.

26 K. Moszyński, Polesie Wschodnie. Materjaty etnograficzne z wschodniej części b. powiatu mozyrskiego oraz z powiatu rzeczyckiego, Warszawa 1928. 
czy znał ją J. Kosiński, za to z pewnością znane mu były opracowania etnograficzne i socjologiczne dotyczące otoczenia, warunków życia, lecznictwa, obyczajów i magii ludu wiejskiego. Poznał je na studiach socjologicznych na Uniwersytecie Łódzkim u Józefa Chałasińskiego, Jana Szczepańskiego i Jana Lutyńskiego. J. Kosiński był po lekturze książek Henryka Biegeleisena: U kolebki. Przed ottarzem. Nad mogita ${ }^{27}$ oraz Lecznictwo ludu polskiego ${ }^{28}$. Te właśnie opracowania i lektury etnograficzne oraz socjologiczne wykorzystał, pisząc Malowanego ptaka ${ }^{29}$.

Musimy pamiętać, że sytuacja „wrzucenia w wędrówkę” wbrew woli Chłopca i rozłąka z rodzicami wydarzyły się z powodu wojny. Ta zupełnie odmienna od znanej mu rzeczywistość zmieniła cały świat małego wędrowca, potęgując rozpacz i przemoc już istniejące na terenach, które przemierzał. Wojna to kolejna z krańcowo dramatycznych sytuacji egzystencjalnych, niebezpieczeństw, wobec których jednostka pozostaje bezradna, zdana na łaskę i niełaskę żołnierzy, przemocy i zniszczenia. Ucieczka, wygnanie i wędrówka w sytuacji wojny nabierają jeszcze bardziej dramatycznego wyrazu. Wiemy, że:

Kojarzenie motywu „trudnej drogi” z ideą próby, rozumianej jako sprawdzian przymiotów bohatera, sprawia, że - mówiąc słowami mitoznawcy - „biografia” bohatera kulturowego sama nabiera charakteru paradygmatycznego, również jako łańcuch krytycznych zdarzeń życia, skorelowanych z „obrzędami przejścia”, wśród których inicjacja często przesłania wszystkie inne. [...] Myśl mityczna przekazuje myśli literackiej całe bogactwo aspektów, w jakie obfituje wizja bohatera wędrującego, podróżującego, czy też błądzącego w labiryncie ${ }^{30}$.

Podróż do jednego z najbardziej zacofanych miejsc Europy Wschodniej i wędrówka po infernalnym krajobrazie wiąże się nieodłącznie z ciągłą walką o przeżycie. Towarzyszy ona życiu Chłopca, który wciąż toczy potyczki o przetrwanie z wrogiem - samą naturą, równie dzikimi i okrutnymi wieśniakami, z Niemcami i Kałmukami polującymi na obcego - Żyda.

27 H. Biegeleisen, Ukolebki. Przed ottarzem. Nad mogita, Lwów 1929.

28 Tenże, Lecznictwo ludu polskiego, Kraków 1929.

29 Pewność co do takich naukowych inspiracji i lektur J.Kosińskiego mają J.P. Sloan, jak też Agnieszka Urszula Przychodzka. Zob.: J.P. Sloan, dz. cyt., s. 86, 88, 174-176; A.U. Przychodzka, dz. cyt., s. $78-79$.

30 A. Wieczorkiewicz, Wędrowcy fikcyjnych światów. Pielgrzym, rycerz i wtóczęga, Gdańsk 1996, s. 6. 
Stopniowo wędrówka staje się coraz trudniejsza, okoliczności groźniejsze, a chłopi bezlitośni. Czytelnik wraz z bohaterem doświadcza chaotycznego tańca przemocy i sadyzmu. Fragmenty powieści J. Kosińskiego zawierające opisy szczególnego okrucieństwa, epatujące ludzkim zdziczeniem, lubowaniem się w przemocy i krzywdzeniu słabszych, napisane rzeczowym i wręcz oszczędnym w metafory językiem, są trudne w odbiorze dla wrażliwego czytelnika.

Chłopiec poznaje gorycz przetrwania za cenę skrajnego poniżenia, smak głodu, poczucie wszechogarniającego strachu i chaos ucieczki, które będą mu towarzyszyły do końca wojny i dalej, aż do odnalezienia zupełnie zapomnianej rodziny. Wędrówka, walka i cierpienie nie tylko w mitach, ale i tekstach literackich, są ze sobą nierozłącznie powiązane, można je „uznać za pewne podstawowe wzorce kształtowania fabuły i za swoiste formy pozwalające wyrażać sens" ${ }^{31}$. Opowieść Chłopca ma w sobie coś z pikarejskiej włóczęgi ukazującej tułaczkę wyobcowanego bohatera wrzuconego w okrutny i chaotyczny świat, zmuszonego do pokonywania coraz to nowych przeszkód i ciągłej walki o przetrwanie. Los nie szczędzi mu upokorzeń, wystawiając na ciągłe próby, a wędrówka przeradza się w ucieczkę przed zagrażającą śmiercią.

Jako topos we współczesnej literaturze podróż:

funkcjonuje przecież jako forma literacka o ogromnej tradycji, znana i rozpoznawana w całym kręgu kultury europejskiej. Nieostrość gatunkowa tych tekstów, wynikająca z wzajemnego przekraczania granic pomiędzy różnymi formami gatunkowymi - przy zachowaniu wyraźnej cechy gatunkotwórczej, jaką jest temat oparty na zewnętrznym wobec tekstu fakcie podróżowania i następnie opisywania własnych przeżyć - wpłynęła na elastyczność tej formy i spowodowała, że jest ona ciągle nośna i otwarta na modyfikacje ${ }^{32}$.

We wspomnieniach wojennych i relacjach z przymusowych wędrówek „podróż - tułaczka stanowi [...] jeden z najważniejszych elementów traumatycznych przeżyć, związanych z utratą domu, poczuciem wygnania i rozpadu starego świata" ${ }^{33}$. Świat Chłopca ulega rozpadowi, znika, a on sam stopniowo zapomina, jak wyglądało życie przed rozpoczęciem podróży w ciemność wojny, traci poczucie tożsamości, przyjmując nową - obcego/

31 Tamże, s. 4I.

32 D. Kozicka, Wędrowcy światów prawdziwych. Dwudziestowieczne relacje z podróży, Kraków 2003, s. 15-16.

33 Tamże, s. 52. 
innego. Ta infernalna podróż to odyseja, exodus, ucieczka przed ścigającymi bohatera okrutnymi, piekielnymi postaciami. Czasem spotyka na swej drodze przewodników po tym zaświatowym krajobrazie, tłumaczących mu sens życia i jego cierpienia (Olga, Lech, Marta, Ksiądz). To uciekinier wędrujący bez konkretnego celu, dla którego najważniejszym wyzwaniem jest pozostać przy życiu, choć wielokrotnie pragnął umrzeć.

Wędrowiec nie przywiązuje się do miejsc, w których przebywa dziś, by jutro, pojutrze, za tydzień, jeśli przeżyje, wyruszyć dalej. Postać wędrowca była jedną z ulubionych w repertuarze bohaterów literackich tworzonych przez J. Kosińskiego; często w taki sposób określał nie tylko swe literackie alter ego, ale samego siebie ${ }^{34}$.

Przebyta droga, podróż o jakiej opowiada Chłopiec, jest nie tylko oparta o określone schematy narracyjne nawiązujące do wielkich i mniejszych tekstów kultury. Stanowi też „uniwersalny wzorzec człowieczego losu, w którym do nieba spełnienia wiedzie droga przez koszmar piekła, zła, z jakim przychodzi się zmierzyć jednostce" ${ }^{35}$. To zanurzenie się w zło, podobne do transgresji, bowiem bohater powieści sam chce w końcu je czynić, opisane przez J. Kosińskiego, nie przynosi Chłopcu jednak niczego innego poza cierpieniem, nie prowadzi do odkupienia czy poznania wiedzy o świecie i sobie samym. Jeśli nawet, to wiedza o naturze człowieczej jest zbyt gorzka, by o niej głośno mówić.

\section{Obcy - inny. Magiczny światopogląd i dualizm kultury ludowej. Wieś w Malowanym ptaku - przemoc, peryferie, natura i dzikość}

Chłopiec, nazywany przez wieśniaków „czarnym”, „przybłędą”, a najczęściej „Żydem” bądź „Cyganem”, jest oczywistą do odczytania dla antropologa postacią z zaświatów, spoza ludzkiej taksonomii, zagrażającą porządkowi orbis interior. Nie zaspakaja standardowych definicji swojskości, nie ma określonego statusu jako członek danej społeczności (w tym przypadku wiejskiej). Znachorka Olga podejrzewa, że jest utopcem, jednym z najgorszych demonów. Wieśniacy lubują się w zadawaniu Chłopcu bólu, krzywdzeniu go na rozmaite sposoby. Jednocześnie boją się go i odwracają wzrok, by nie patrzeć w jego czarne, uroczne oczy, żeby nie policzył im zębów, skracając tym samym życie. Jako przedstawiciel nadprzyrodzonego świata

34 J. Kosiński Czas wolny, [w:] Przechodząc obok, przeł.Z. Kański, E. Kulik i in., Warszawa 1994, s. 23.

35 P. Kowalski, Odyseje nasze byle jakie. Droga, przestrzeń ipodróżowanie w kulturze wspótczesnej, Wrocław 2001, s. 134 . 
z zewnątrz mógłby na nich rzucić urok i spowodować kalectwo, a nawet śmierć. Wyraźnymi elementami opisu obcych, w tym przypadku Chłopca, pozostają demoniczność, niesamowitość, deformacja, niczym w zoomorficznych postaciach wielu bóstw w religiach społeczeństw pierwotnych ${ }^{36}$. Wiele z cech tego opisu możemy odnaleźć w światopoglądzie tradycyjnym ${ }^{37}$. Dlatego też bohater jest po wielokroć uważnie oglądany przez wieśniaków szukających na jego ciele znamion świata demonicznego.

Największą korzyść z jego zaburzonej kulturowej taksonomii czerpią znachorka Olga i ptasznik Lech, sami zresztą, wedle ludowego światopoglądu, usytuowani po stronie obcości, żyjący z dala od wiejskich wspólnot, a więc bliscy bohaterowi. Na szczególną uwagę zasługuje tu rola pomocnika uzdrowicielki, jaką Chłopiec pełni przez dłuższy czas, poznając zasady rządzące światem zdrowia i choroby, magii i lecznictwa ludowego oraz światem nadprzyrodzonym. Leczeniem, jak i powodowaniem chorób (rzucaniem uroków), wymagającym wiedzy i odpowiednich mocy, wedle tradycyjnego światopoglądu,

powinni zajmować się ludzie, którzy znajdują się poza społecznością, a zatem są w jakimś sensie obcy [...] Znachorzy, zielarze, osoby poszukujące ziół w odludnych miejscach i w niebezpiecznych, progowych momentach cyklu dobowego, również mieszkają na skraju wsi, pod lasem, bądź w leśnej głuszy. [...] Najskuteczniejsi byli w zamawianiach przedstawiciele obcych nacji. Wypowiedziane przez Cygana, Żyda czy innego obcokrajowca obce, niezrozumiałe słowa albo nawet cytat z Biblii, nabierały dodatkowej mocy ${ }^{38}$.

Szczegółowe opisy leczenia chorób, wierzeń dotyczących rzucania uroków i magicznych znaczeń przypisywanych w kulturze ludowej określonym częściom ciała, obecne w Malowanym ptaku, możemy odnaleźć zarówno w wymienianych już opracowaniach $\mathrm{H}$. Biegeleisena oraz A. Palucha ${ }^{39}$, jak też w innych lekturach znanych antropologom.

Mądra Olga - znachorka - wprowadza Chłopca w nadprzyrodzony świat pełen demonicznych duchów, upiorów i strzyg. Opowiada o przyczynach chorób i magicznych sposobach ich leczenia, zasadach zbierania i przechowywania ziół, sporządzania leczniczych eliksirów i odczyniania

36 Z. Benedyktowicz, Portrety „obcego”. Od stereotypu do symbolu, Kraków 2000, s. 162.

37 J.S. Bystroń, Megalomania narodowa, Warszawa 1995, s. 50-6I.

38 P. Kowalski, Leksykon znaki świata. Omen, przesąd, znaczenie, Warszawa 1998, s.366-367.

39 A. Paluch, Etnologiczny atlas ciata ludzkiego i chorób, Wrocław 1995. 
uroków. Jednak i ona, mimo ogromnej wiedzy i doświadczenia, jest bezradna wobec epidemii śmiertelnej zarazy pustoszącej całe wioski. Udaje jej się uratować Chłopca poprzez zakopanie go po szyję w ziemi, pozostawienie pod jej opieką, by „wyciągnęła” chorobę ${ }^{40}$. Dzięki opiece Olgi Chłopiec zostaje wtajemniczony w tajniki magii leczniczej, rolę zła na świecie oraz istnienie odpowiadających za nie ciemnych, diabolicznych sił - upiorów, uroków i czarnej magii. Mądra Olga roztacza przed nim wizję istnienia dwóch sił, dwóch porządków ontologicznych, toczących ze sobą nieustanną walkę o ludzkie dusze. On sam, ze względu na wygląd, pochodzenie i wszelkie widoczne (i te ukryte) znaki - signum obcości - jest sytuowany po stronie zła, budząc obrzydzenie i strach chłopów. Bohater akceptuje takie wytłumaczenie swego losu jako groźnego dla ludzkiej ekumeny wysłannika złych sił, poddając się zabiegom i naukom znachorki, jak i samemu biegowi wypadków. Zresztą również i jej boją się włościanie, uważając za czarownicę, która tylko z niewiadomego im kaprysu leczy choroby i odczynia uroki.

Podobnie niezwykły, odmienny od większości wieśniaków, jest Lech. Marzyciel, znawca ptaków, lasu i tajników przyrody. Jak nikt potrafi zakładać gniazda, do których zawsze wracają bociany, uznawane w kulturze ludowej za przynoszące domowi szczęście, łapać ptaki i sprzedawać je chętnym nabywcom. Jest odludkiem, rodzajem mędrca bliskiego światu natury. Od niego Chłopiec uczy się, jak przeżyć w leśnej kniei, jak rozumieć, o czym mówi do niego las i przed czym ostrzegają zwierzęta ${ }^{41}$. Lech zdaje się znać nie tylko wszelkie zwyczaje ptaków, ale nawet rozumieć ich mowę. Choć wykorzystuje bohatera do niebezpiecznych zadań, jak wspinanie się na sam szczyt wysokich drzew w poszukiwaniu gniazd, jest dla niego dobry, nie krzywdzi go, rozpoznając w nim podobnego sobie odmieńca. Poza tymi dwiema ważnymi postaciami, których narracja łączy z Chłopcem przez dwa rozdziały powieści, inni mieszkańcy terenów, przez które wędruje bohater, okazują się źli, wręcz diaboliczni, jak torturujący go w sadystyczny sposób chłop Garbosz czy bijący z byle powodu Młynarz.

40 Niestety, brak tu miejsca na szczególowe opisy i cytaty z Malowanego ptaka, dotyczące leczniczych działań znachorki i ludowych wierzeń dotyczących chorób, demonów i obcych. Zauważmy tylko, że wiara w leczniczą moc ziemi jako żywiołu była silnie obecna w kulturze ludowej. Zob.: Stownik stereotypów i symboli ludowych, t. I, z. 2, red. J. Bartmiński, Lublin 1999 .

41 Antropolog kultury odnajdzie w tych fragmentach powieści wpływ klasycznych etnograficznych opracowań dotyczących świata przyrody i zwierząt, wierzeń i symboliki z nimi związanej autorstwa Kazimierza Moszyńskiego, Oskara Kolberga oraz innych znawców kultury duchowej i materialnej mieszkańców dawnej wsi. Nie mamy pewności, czy były znane J. Kosińskiemu, wskazuje na to jednak sama treść Malowanego ptaka. 
Światopogląd i wierzenia mieszkańców wsi w Malowanym ptaku możemy określić mianem typowych dla ludowego pojmowania świata, doskonale znanych antropologom jako system naturalistyczno-religijny. Obejmował on wiarę w ożywienie całej natury, często brak rozróżnienia magii od religii, istnienie istot nadprzyrodzonych towarzyszących człowiekowi; albo wobec niego wrogich (częściej), albo przychylnie nastawionych. Kosmos był postrzegany jako żywy organizm, a istoty ludzkie, zwierzęta i rośliny stanowiły razem jego części. Istotę relacji pomiędzy ludźmi a przyrodą stanowiła zasada wzajemności i respektowania reguł współistnienia we wspólnocie. Dualizm dotyczył wiary w istnienie dwóch opozycyjnych wobec siebie sił - boskiej i diabelskiej, dobrej i złej. Wierze we współpracę przyrody w celu podtrzymywania życia przeciwstawiona była wiara $\mathrm{w}$ istnienie nieprzychylnej ludziom, opozycyjnej siły związanej ze śmiercią, chorobami, zniszczeniem, zimą i nocą. W podobny sposób, jako przynależące do porządku dobra i zła, klasyfikowano zwierzęta i rośliny, zdrowie i choroby, istoty demoniczne i zjawiska pogodowe, pory roku oraz rytmy natury. Podobnej waloryzacji podlegało także ludzkie ciało i przestrzen' ${ }^{42}$. Sądzę, że nie ma tutaj potrzeby szczególowego omawiania powszechnie znanych etnologom zasad i lektur, wystarczy uwaga, że ich tropy są wyraźnie widoczne w Malowanym ptaku, zarówno w opisie warunków życia i obyczajów wsi, jak i wierzeń jej mieszkańców. Zasady demonologii ludowej Chłopiec poznaje od znachorki Olgi, świat przyrody i zwierząt od ptasznika Lecha, a prawidła wiary katolickiej od księdza tłumaczącego je staremu chłopu:

Nagle porządek świata objawił mi się z niezwykłą jasnością. Zrozumiałem, dlaczego jedni są silni, inni słabi, jedni wolni, drudzy zniewoleni, jedni bogaci, inni biedni, jedni zdrowi, drudzy schorowani. Ci pierwsi po prostu wcześniej uzmysłowili sobie potrzebę odmawiania pacierzy oraz zbierania odpustów. Gdzieś w niebie odpowiednio segregowano napływające z ziemi modlitwy; każdy człowiek miał swój kosz, w którym przechowywano zgromadzone przez niego odpusty. [...] Przestałem oskarżać innych; zrozumiałem, że sam jestem sobie winien. Byłem zbyt głupi, by odkryć zasadę rządzącą światem ludzi, zwierząt i wydarzeń. Dopiero teraz przekonałem się, że na świecie panuje jednak ład i sprawiedliwośćc ${ }^{43}$.

42 Zob. m.in.: J. Tomicka, R. Tomicki, Drzewo życia. Ludowa wizja świata i cztowieka, Warszawa 1975; A.Zadrożyńska, Powtarzać czas początku, cz. I, Warszawa 1986; A. Zadrożyńska, Powtarzać czas początku, cz. II, Warszawa 1988.

43 J.Kosiński, Malowany..., s. 166. 
W dalszym ciągu wędrówki, pod wpływem doznanych cierpień i rozczarowania religią, Chłopiec postanawia tym razem stanąć po stronie Szatana, czyniąc zło i krzywdząc innych, a nawet zaprzedać duszę Diabłu, jeżeli tylko będzie miał taką możliwość. Bohater, mimo starań i prób akceptacji elementów tradycyjnego światopoglądu, nie potrafi jednak zrozumieć przyczyny niesprawiedliwości na świecie dotykającej go osobiście. Od pułapki tej „fałszywej świadomości” , „ciemnoty” i „zabobonów religijnych” ratuje go dopiero spotkanie z Czerwonoarmistami - Mitką i Gawryłą, zaszczepiających w małym synu pułku nową wiarę - ideologię marksistowską ${ }^{44}$. Staje się ona lekarstwem na wszelkie wątpliwości, a wiara w nowy, lepszy komunistyczny ład, jakiej wyznawcą staje się Chłopiec, daje mu siłę potrzebną do życia. Wolny od dotychczasowych trosk, wreszcie bezpieczny i kochany przez żołnierzy radzieckich jak młodszy brat, uczy się pisać i czytać (po rosyjsku), poznaje marksistowską wizję historii ludzkich dziejów. Czerwonoarmiści ratują mu życie.

To dzięki nim, po pobycie w wojskowym szpitalu, budzi się do nowej tym razem, jak wierzy, prawdziwej egzystencji. Jest przekonany o słuszności wybranej drogi ku świetlanej przyszłości i tożsamości nowego, sowieckiego człowieka. Cieszy go udział w prawdziwej, braterskiej wspólnocie komunistów pragnących zniszczyć niemiecki faszyzm i zakończyć wszelką niesprawiedliwość na świecie. W tym laickim światopoglądzie bohater nareszcie odnajduje pociechę i jasne wytłumaczenie przyczyn swej tragicznej sytuacji.

Przemoc jest nieodłączną częścią wiejskiego świata, w jakim znalazł się Chłopiec. Towarzyszy mu aż do końca jego wędrówki. W piekle zadawanego bólu jest świadkiem niezliczonych aktów agresji. Chłopi czerpią z niej wyraźną przyjemność, bawi ich ona, a nawet jeśli tak nie jest, to przemoc dla mieszkańców wsi stanowi najzwyklejszy i zarazem najprostszy sposób rozwiązywania wszelakich sporów i problemów. O ile jednak w obserwowanej przez chłopca naturze agresja jest nieświadoma, niejako pierwotna, o tyle chłopi nie tylko są jej świadomi, ale wręcz upajają się nią. Przedstawiony w drastycznych scenach los Chłopca nie powinien być niczym nowym dla polskiego czytelnika. Opis wojennych doświadczeń Zagłady jest „znany w literaturze polskiej z zapisów Jerzego Andrzejewskiego, Zofii Kossak-Szczuckiej, Zofii Nałkowskiej i Tadeusza Borowskiego. Były nim przeżycia II wojny światowej, okupacji, zagłady Romów i Żydów" ${ }^{45}$. Porażający jest

\footnotetext{
44 Wedle Ludmiły Gruszewskiej Blaim, Chłopiec funkcjonuje kolejno w trzech rodzajach kulturowej rzeczywistości, starając się równocześnie przyjąć jako swoje własne ich modele pojęciowo-tożsamościowe: baśniowo-magiczny, religijny i marksistowski. Zob. L. Gruszewska Blaim, Gra w SS. Poetyka (nie)powieści Jerzego Kosińskiego, Lublin 2005, s. 27.

45 A.U.Przychodzka, dz. cyt., s. 78 .
} 
skrajny realizm i oszczędność środków literackich, za pomocą których J. Kosiński przedstawił wędrówkę Chłopca wpisującą się w pamięć Holocaustu. Pisarz w dziele na wskroś realistycznym stworzył iluzję wiarygodną tak bardzo, że aż domagającą się od czytelnika wiary w jej obiektywne istnienie. Malowany ptak zawiera wiele okrutnych aktów przemocy,

przesiąknięty jest dramatyzmem i drastycznością scen brutalnych (wydłubywanie oczu, najazd Kałmuków, samosądy i akty zemsty), które dla polskiego czytelnika nie są nowe. Znamy je z opowieści naocznych świadków, szkolnych lektur i filmów czy literatury epok minionych (Krzyżacy Sienkiewicza, Chtopi Reymonta czy Pani Bovary Flauberta). Niestety, dokonując interpretacji stosunkowo nowego tekstu, zapominamy o kanonie klasycznym"46.

Przemoc obecna w powieści J. Kosińskiego dotyka bohatera na każdym kroku, zarówno jako doświadczenie osobiste, jak i zasada funkcjonująca w otaczającym świecie przyrody i ludzi. Sceny pełne przemocy łączą się z opisami wyuzdanego seksu, tworząc wspólnie przedziwny konglomerat rodem z pornograficznej estetyki brzydoty. Czytelnik może odnieść wrażenie, że to połączenie jest główną cechą charakteryzującą piekielny, zdeformowany świat wiejskich peryferii.

Jest to świat zamknięty, z wyraźnie określonymi granicami. Mieszkańcy wiosek nigdy nie zapuszczają się poza ich granice. Przy czym zamknięcie dotyczy nie tylko sfery przestrzeni (izolacja horyzontalna, geograficzna), ale także wspólnoty i jej kultury (izolacja wertykalna), tworząc izolację świadomościową, sprzyjającą kształtowaniu dyskursu mitycznego. Nieuświadamiany, organizuje on wszelkie sfery ludzkiej aktywności wedle swych zasad (umiejscawianie, rozpoznawanie i niepoznawanie). Centralną opozycją w tego typu światopoglądzie pozostaje zróżnicowanie orbis interior - orbis exterior ${ }^{47}$. Stąd traktowanie wszystkiego (w tym Chłopca), co pochodzi spoza granic bezpiecznej przestrzeni jako obcego i niebezpiecznego na tyle, by móc czuć się uprawnionym nawet do okrutnego potraktowania/ zniszczenia elementu/ lub istoty spoza ludzkiej ekumeny.

Tak więc, świat wiejskich peryferii z Malowanego ptaka wykazuje znaczne podobieństwa do kultury typu ludowego. Jednak wykreowana przez pisarza rzeczywistość przewyższa ją zamiłowaniem do stosowania przemocy. Niedostępne wioski - peryferie otoczone gęstymi lasami, leżące pośród bagien, charakteryzują się zupełnie odmiennymi od kulturowego i cywilizacyjnego

46 Tamże, s. $78-79$.

47 Zob.: L.Stomma, dz. cyt., s. I43-147. 
centrum cechami - wyznacznikami dalekiego pogranicza rodem z opowieści niesamowitych. Nie istnieje tam żadna inna od pierwotnej, naturalnej, forma władzy ani jej społeczne instytucje. Otoczenie wiosek przypomina obszar zaświatowy, pustkowie, którego cechy w kulturze ludowej sytuowały się po stronie orbis exterior:

Las stawał się coraz gęstszy, coraz bardziej ponury. Oślizgłe pnie grabów, nakrapiane niczym cielsk węży, wznosiły się strzeliście w niebo, muskając wierzchołkami chmury. Lipy, które według Lecha pamiętały zamierzchłe początki ludzkości, stały niewzruszone, podobne do barczystych wojów zakutych w żelazne, zaśniedziałe mchem zbroje. Pnie dębów wyciągały do góry szyje niczym zgłodniałe ptaki wypatrujące pokarmu, a ich posępne konary zasłaniały słońce, pogrążając w głębokim cieniu sosny, topole i lipy. Czasami Lech przystawał i w milczeniu spozierał na ślady widoczne w pęknięciach gnijącej kory, sęki i galasy, gdzie z dna dziwacznych czarnych dziur wyzierało gołe białe drzewo ${ }^{48}$.

Las gnije, nie ma w nim jasnych barw i wesołego świergotu ptaków, wszędzie czają się rozkład, strach i śmierć, skryte w półmroku. W tym groźnym otoczeniu łatwo zabłądzić, nie ma w nim bowiem dróg ani wyraźnie zaznaczonych kierunków. Tylko ptasznik Lech, jako istota bliższa naturze niż reszta mieszkańców peryferii, potrafi poruszać się w dzikiej kniei. Chłopi nie zapuszczają się daleko w leśne ostępy, groźne i pełne demonów. Po kolejnej ucieczce z wiejskiego domostwa Chłopiec spędza noc w lesie. Przez dłuższy czas jest to dla niego schronienie przed złymi wieśniakami chcącymi dla zysku wydać go Niemcom czy dla rozrywki zabić. Podczas pobytu u znachorki Olgi i łowcy ptaków Lecha poznał tajniki wiedzy potrzebnej do przetrwania w dzikich ostępach lasu nawet zimą. Bohater radzi więc sobie świetnie, mimo grozy, jaką początkowo napawa go dziki las. Nie tylko sama natura, ale pory roku są groźne i odmienne od tych znanych Chłopcu. Ziemia jest marna i nieurodzajna, a nędzne wioski ukryte wśród leśnego pustkowia. Najgorsza jest zima, padający tygodniami śnieg i skuwający ziemię mróz. Zimą, porą roku charakterystyczną dla złej, śmiercionośnej strony natury, wioski zamierają w bezruchu. To kolejna metonimia śmierci w opisie wiejskich terenów, obecna w powieści J. Kosińskiego:

Po wczesnej jesieni, która zniszczyła część plonów, nastała sroga zima. Potem nadciągnął mróz, skuwając na kość wszystko pod śniegiem. [...] Nikt nie 
chciał mnie wziąć do siebie. Żywności brakowało, każda dodatkowa gęba stanowiła poważne obciążenie. [...] Zima nie zwalniała uścisku. Ciężkie niebo, zasnute ołowianymi chmurami, zdawało się przygniatać do ziemi kryte strzechą chaty ${ }^{49}$.

Niskie, pochmurne ciemne niebo jest stałym atrybutem wiejskiej przestrzeni. Słońce wyłania się zza chmur jedynie po to, by można było ujrzeć sceny cierpienia ludzi i zwierząt. Szalejące burze, wichury, pioruny, zamiecie śnieżne i ulewne deszcze to nieodłączne cechy tej groźnej przestrzeni peryferyjnej.

Nawet jeśli wraz z Chłopcem przeżywamy wędrówkę w letniej porze, wciąż odczuwamy grozę śmierci czyhającą gdzieś w oddali. Świat peryferii nie zna przestrzeni bezpiecznych, sielankowych. Niebezpieczeństwo i śmierć zawsze czają się w pobliżu: „W opisach wschodnich regionów kraju przedstawionych przez narratora wewnętrznego, pojawiają się obrazy, wyraźnie nawiązujące do motywu jałowej ziemi - znanego z tekstów kultury i literatury - przestrzeni, nad którą wisi widmo zagłady" ${ }^{50}$. W tym, co u J. Kosińskiego dla literaturoznawcy jest odniesieniem do „ziemi ulro”, „ziemi jałowej”, antropolog kultury rozpoznaje cechy bliskie opisowi orbis exterior, zaświatowej przestrzeni pustkowia w kulturze ludowej. Nie tylko miejsca i okolice, przez jakie wędruje Chłopiec są nieprzyjazne, groźne i skażone zaświatowością. Ich mieszkańcy mają w sobie coś z dzikich zwierząt, jednak przewyższają je w zamiłowaniu do okrucieństwa. Jakby sama okrutna natura zaraziła ich złem i okaleczyła brzydotą:

Opisy mieszkańców peryferii sugerują, iż postaci pozostają tu w relacji ekwiwalentnej do otaczającego ich świata. Jak wynika z wypowiedzi pierwszoosobowego narratora, są oni równie ponurzy, zamknięci w sobie i nieestetyczni. [...] Charakterystyka postaci zamieszkujących tę jałową ziemię aż nazbyt widocznie wyzyskuje metaforykę roślinną i zwierzęcą - dominuje ona zarówno w opisach ich wyglądu, jak i zachowań. [...] To między innymi dzięki metaforyce i porównaniom rysuje się przewaga, jaką na tych obszarach ma przestrzeń natury nad przestrzenią kultury ${ }^{51}$.

W tym dzikim świecie przemoc jest powszechnie obecna jako metoda wychowawcza, najlepszy sposób rozwiązywania wszelkich problemów,

\footnotetext{
49 Tamże, s. IO2.

50 L. Gruszewska Blaim, dz. cyt., s. 28.

51 Tamże, s. 30.
} 
rozrywka, a nawet rodzaj komunikacji z innymi: ,jak dowodzi relacja pierwszoosobowego narratora, przemoc jest na peryferiach zjawiskiem nie tylko powszechnym, ale i wszechstronnie funkcjonalnym" ${ }^{52}$. Przemoc i śmierć, jakich doświadcza Chłopiec, ukazują wiejską rzeczywistość jako całkowicie podporządkowaną podstawowym instynktom samozachowawczym, prawie pozbawioną praw i norm moralnych. Jedynym i powszechnym prawem jest prawo silniejszego i jego pięści.

Czytelnik znajdzie w powieści J. Kosińskiego przemoc we wszelkich możliwych postaciach: uśmiercanie zwierząt dla zabawy, zabójstwa, gwałty, tortury, śmiertelne bójki, egzekucje, rekwizycje i kary nakładane na wieśniaków przez partyzantów, wojna i horror szalejących sił destrukcji, a wreszcie apokaliptyczny najazd Kałmuków na spokojną wieś. Chłopiec przyjął od mieszkańców peryferii zasadę akceptacji prawa silniejszego, neutralności wobec niezrozumiałych konfliktów i mimikry, stosowania się do norm rządzących zachowaniem wieśniaków. Zobojętniały na obserwowaną i doświadczaną przemoc, dzięki temu przetrwał tak długo. Nie zamierzam tu epatować cytatami z Malowanego ptaka zawierającymi niesłychane okrucieństwo pornografii przemocy. Jak sądzę, wystarczy omówienie znaczeń i funkcji, jakie jej opisy pełnią w powieści.

\section{Malowany ptak jako uniwersalna metafora ludzkiego losu i ostrzeżenie}

Najbardziej znana i kontrowersyjna powieść J. Kosińskiego była odczytywana przez literaturoznawców jako bliska powieści pikarejskiej, anty-baśni czy Bildungsroman ${ }^{53}$. Inni badacze widzieli w niej motyw podrzutka, dziecka wykradzionego rodzicom, a nawet figurę dzikiego dziecka dorastającego w dżungli i żyjącego w ścisłym związku z przyrodą, odrzucającego ludzki świat, w odwiecznym konflikcie „natura - kultura”, jako pełen niegodziwości ${ }^{54}$. Rzeczywiście, powieść jest przesycona okrucieństwem niby zła baśń braci Grimm. Nie zapominajmy, że J. Kosiński musiał nim epatować, by przyciągnąć amerykańskiego czytelnika:

Ani odległość świata leżącego za „lasami, za bagnami”, ani naiwność dziecka zachowana w narracji pierwszoosobowego narratora nie łagodzi szoku, jaki w czytelniku wywołuje kontakt z obrazem świata oraz antybohatera

52 Tamże, s.3I.

53 Tamże, s. 26-27, 62.

54 A.U.Przychodzka, dz. cyt., s. 8o-8r. 
z Malowanego ptaka. [...] Tłem pierwszego etapu dojrzewania dziecka - jednostki pozbawionej wszelkich barw ochronnych - jest kulturowe pogranicze stanowiące „archiwum anomalii” (sensu Lotman), w ramach którego Obcemu jest przypisywany pełen zestaw negatywnych, sprzecznych wewnętrznie $\operatorname{cech}^{55}$.

Ludmiła Gruszewska Blaim zauważa, że epizody z wędrówki Chłopca rozgrywające się w scenerii peryferyjnych wiejskich społeczności, opisy obyczajów, wierzeń, aksjologii dowodzą socjologicznych zainteresowań twórcy Malowanego ptaka. Omawiana książka pozostała najsłynniejszą powieścią J. Kosińskiego, a ogromnego wrażenia wywartego na publiczności amerykańskiej i światowej dzięki zawartemu w narracji skrajnemu dramatyzmowi pisarz nie zdołał więcej powtórzyć. Malowany ptak nie jest:

studium psychologicznym ani socjologicznym. Nie jest też popisem zdewiowanego umysłu, który gustuje w okropieństwach i narcystycznych projekcjach - jest wypowiedzią artystyczną prezentującą niepowtarzalny obraz kształtowania się powieściowej postaci, której doświadczenia mogą - choć ze względu na zawarcie paktu powieściowego nie muszą - być modelowane na faktycznych losach autora ${ }^{56}$.

Na pewno brak w Malowanym ptaku literackiego odzwierciedlenia schematu tradycyjnego obrzędu przejścia, inicjacyjnej wędrówki. O ile bowiem podróż Chłopca zawiera w sobie element wrzucenia w wędrówkę, fazę separacji/wyłączenia (z charakterystycznymi dla niej okaleczeniami, nagością, torturami, izolacją oraz fazę liminalną ze stratą dotychczasowego statusu), o tyle faza postliminalna/włączenia do społeczności nie jest w pełni obecna. Bohater nie zyskuje nowego statusu, przeszłość tkwi w nim zbyt mocno, by mógł o niej zapomnieć. Nie pragnie reintegracji ze społeczeństwem ani zyskania nowej tożsamości. Owszem, wiedza, jaką zdobywa w trakcie swej wędrówki, odnosi się do ogólnoludzkiej kondycji, jednak zawiera w sobie wyłącznie negatywny aspekt. W wyniku jej poznania Chłopiec postrzega innych ludzi jako potencjalne zagrożenie, nie pragnie nawiązania bliskich, emocjonalnych kontaktów. Bliżej mu do stwierdzenia homo homini lupus. Wiejska rzeczywistość zobrazowana w Malowanym ptaku stanowi zaś archetypiczny obraz odmieńca w relacji ze społeczeństwem. Jest on zresztą obecny w wielu innych książkach J. Kosińskiego przybierającego często

55 L. Gruszewska Blaim, dz. cyt., s. 66-67.

56 Tamże, s. 68. 
maskę wiecznego outsidera. Przemoc tak wyraźnie obecna w powieści (jak również inne elementy świata przedstawionego, miejsca, osoby i zdarzenia) może podlegać podobnym faktograficznym przemieszczeniom. I z tego czytelnik powinien zdawać sobie sprawę. Antropolog kultury dostrzeże w Malowanym ptaku pewną sprzeczność. Jeśli kulturę wiejską i samych chłopów potraktujemy jako związaną z naturą, to jak ma się do tego przypisania opisywane po wielokroć upajanie się okrucieństwem? Czy więc obrazy okrucieństwa zostają przypisane wsi, należą do obrazu wojny lub są reakcją na obecność Obcego? Wreszcie, czy chłopi należą do świata natury (wedle idei powieści), czy powinni zostać z niego jednak wyłączeni?

Lektura powieści J. Kosińskiego wymaga głębszej refleksji nad człowieczeństwem i jego brakiem, także we współczesnej kulturze europejskiej. Wymaga wyjścia poza historyczny i literacki krąg kata i ofiary, Niemca i Żyda, swojskości i obcości. Jako taka, metaforycznie odczytana, stanowi ważne ostrzeżenie także w czasach nam współczesnych.

\section{Bibliografia}

\section{Literatura}

Antropologia literatury. Interpretacje i studia, red. E. Feliksiak, Kraków 2014.

Benedyktowicz Z., Portrety „obcego”. Od stereotypu do symbolu, Kraków 2000.

Biegeleisen H., Lecznictwo ludu polskiego, Kraków 1929.

Biegeleisen H., Ukolebki. Przed ottarzem. Nad mogita, Lwów 1929.

Bojarska K., Trauma, [w:] Modi memorandi. Leksykon kultury pamięci, red. M. Saryusz-Wolska, R. Traba, Warszawa 2014.

Bystroń J.S., Megalomania narodowa, Warszawa 1995.

Culler J., Teoria literatury, przeł. M. Bassaj, Warszawa 1998.

Dasko H., Odlot malowanego ptaka, Warszawa 2009.

Draaisma D., Dlaczego życie ptynie szybciej, gdy się starzejemy, przeł. Ewa Jusewicz-Kalter, Warszawa 2006.

Eliade M., Aspekty mitu, przeł. P. Mrówczyński, Warszawa 1998.

Eliade M., Próba labiryntu. Rozmowy z Claude-Henri Rocquetem, przeł. K. Środa, Warszawa 1992.

Grass G., Przy obieraniu cebuli, przeł. S. Bałut, Gdańsk 2007.

Gruszecka Blaim L., Gra w ss. Poetyka (nie)powieści Jerzego Kosińskiego, Lublin 2005.

Janion M., Kobiety i duch inności, Warszawa 2006.

Kępiński M., Pomiędzy pamięcią autobiograficzna a zbiorową. Polska ludowa i stan wojenny w narracjach tódzkich nauczycieli, Łódź 2016.

Kosiński J., Malowany ptak, przeł. T. Mirkowicz, Warszawa 1995. 
Kosiński J., Przechodząc obok, przeł. Z. Kański, E. Kulik i in., Warszawa 1994.

Kowalski P., Leksykon znaki świata. Omen, przesąd, znaczenie, Warszawa 1998.

Kowalski P., Odyseje nasze byle jakie. Droga, przestrzeń i podróżowanie w kulturze wspótczesnej, Wrocław 200I.

Kozicka D., Wędrowcy światów prawdziwych. Dwudziestowieczne relacje z podróży, Kraków 2003. Kulturowa teoria literatury. Gtówne pojęcia i problemy, red. M. Markowski, R. Nycz, Kraków 2010.

Markowski M.P., Antropologia i literatura, „Teksty Drugie” 2007, nr 6.

Maruszewski T., Pamięć autobiograficzna, Gdańsk 2005.

Modi memorandi. Leksykon kultury pamięci, red. M. Saryusz-Wolska, R. Traba, Warszawa 2014.

Moszyński K., Polesie Wschodnie. Materjaty etnograficzne z wschodniej cześsi b. powiatu mozyrskiego oraz z powiatu rzeczyckiego, Warszawa 1928.

Okupnik M., Fenomen pamięci. O trudnościach badań narracji autobiograficznych o stracie, „Acta Universitatis Lodzensis. Folia Sociologica" 2012, nr 4I.

Ossendowski A.F., Polesie, Poznań 2010.

Paluch A., Etnologiczny atlas ciata ludzkiego i chorób, Wrocław 1995.

Pruszyński K., Podróź po Polsce, Warszawa 2000.

Przychodzka A.U., Zatracona tożsamość Jerzego Kosińskiego. Doświadczanie Holocaustu, Łódź 2006.

Rydlewski M., „Spór o kosę” w Konopielce Edwarda Redlińskiego a zmienne treści percepcyjne schematów pojęciowych, „Etnografia Polska” 2017, t. LXI, z. I-2.

Siedlecka J., Czarny ptasior, Warszawa 201 I.

Skarga B., Tożsamość Ja i pamięć, „Znak” 1995, nr 5.

Sloan J.P., Jerzy Kosiński. Biografia, przeł. E. Kulik-Bielińska, Warszawa 1997.

Stownik rodzajów i gatunków literackich, red. G. Gazda, Warszawa 2012.

Stownik stereotypów i symboli ludowych, t. I, z. 2, red. J. Bartmiński, Lublin 1999.

Stomma L., Antropologia kultury wsi polskiej XIX wieku, Warszawa 1986.

Tomicka J., Tomicki R., Drzewo życia. Ludowa wizja świata i cztowieka, Warszawa 1975.

Wieczorkiewicz A., Wędrowcy fikcyjnych światów. Pielgrzym, rycerz i wtóczega, Gdańsk 1996.

Zaleski M., Formy pamięci, Gdańsk 2004.

Ziejka F., Ztota legenda chtopów polskich, Warszawa 1984.

Zadrożyńska A., Powtarzać czas początku, cz. I, Warszawa 1986.

Zadrożyńska A., Powtarzać czas początku, cz. II, Warszawa 1988.

Streszczenie: Tekst porusza tematykę obrazów polskiej wsi, obecnych w Malowanym ptaku Jerzego Kosińskiego. Analizy dokonano z punktu widzenia antropologii kulturowej, między innymi poprzez kategorie: swój - obcy, orbis interior - orbis exterior, centrum - peryferie, wędrówka, dziecko. Przy antropologicznym dekodowaniu tekstu literackiego o charakterze autofikcji autor artykułu posługuje się pomocnymi w tym działaniu terminami antropologii pamięci: autobiografią, pamięcią autobiograficzną, traumą. Polska wieś czasów Holocaustu, ukazana w pozie J.Kosińskiego, okazuje się przestrzenią wędrówki 
głównego bohatera, bliską naturze, położoną w obszarze dalekich peryferii kultury i cywilizacji. Tragiczna w wielu wymiarach podróż, choć bliska inicjacyjnej wędrówce, jednak nie jest nią. Powodem jest brak ostatniego, trzeciego elementu charakterystycznego dla klasycznego schematu obrzędów przejścia według Arnolda van Gennepa. Mieszkańcy wsi, ich życie i wierzenia ukazane zostały jako zgodne z etnograficznymi i socjologicznymi opracowaniami tematu. Powieść należy do nurtu krytycznie traktującego tematykę wiejską we współczesnej literaturze.

Słowa klucze: literatura, pamięć, wieś, wędrówka, trauma, kultura ludowa

Summary: The article concerns the subject of image of the Polish village present in The Painted Bird by Jerzy Kosiński. Analysis is made from a point of view of the cultural anthropology using categories: own - fereign, orbis interior - orbis exterior, centre - outskirts, journey, child. In the anthropological decoding of the novel, the author of the article uses the terms of anthropology of memory that are helpful in this regard: autobiography, autobiographical memory, and trauma. The Polish village of the times of the Holocaust, shown in the novel, turns out to be a space for the hero's journey, close to nature, located in the distant periphery of culture and civilization. Yet it is not a journey of initiation. The reason is the lack of the last, third element characteristic of the classical scheme of the rites of passage according to Arnold van Gennep. Inhabitants of the countryside, their lives and beliefs are shown as consistent with the ethnographic and sociological studies of the topic. The novel belongs to a trend that critically treats rural themes in contemporary literature.

Keywords: literature, memory, village, journey, trauma, folk culture 